Ekspansi: Jurnal Ekonomi, Keuangan, Perbankan dan Akuntansi

ISSN (Online): 2580-7668 ISSN (Print): 2085-5230

Vol. 12, No. 2 (November 2020), Hal. 169 - 177

\title{
PENGARUH GAYA KEPEMIMPINAN TERHADAP PRODUKTIVITAS KERJA PEGAWAI DI PEMERINTAH DAERAH
}

\author{
Lili Indrawati ${ }^{1}$, Etti Ernita Sembiring ${ }^{2}$ \\ ${ }^{1,2}$ Jurusan Akuntansi, Politeknik Negeri Bandung, Kota Bandung, Indonesia \\ Email Korespondensi: lili.indrawati@polban.ac.id
}

\begin{abstract}
The purpose of this research is to analyze and prove the role of leadership style against employee productivity in local government. The leadership style studied combines human-oriented and task-oriented leadership styles. This is because each leadership style has weaknesses. The task-oriented leadership style focuses on the technical aspects by explaining work procedures but does not pay attention to the motivation and welfare of subordinates. Human-oriented leadership style focuses on positive relationships, creates good teamwork. However, this leadership style also has a weakness, namely that the actual goal becomes weak. A good leadership style is a leadership style that can combine these two leadership styles. The research was carried out at the Bandung Local Government. The number of respondent was 4 persons each from 27entity from West Bandung Local Government. The entity which are used as sample in this research are finance office. Regression is used to analyze the data from the respondent. The research shows that leadership style does affect positive significantly the employee productivity of local government.
\end{abstract}

Keywords: Leadership Style, Employee Productivity, Local Government.

Abstrak: Penelitian ini bertujuan untuk menguji pengaruh gaya kepemimpinan terhadap produktivitas kerja pegawai. Gaya kepemimpinan yang diteliti menggabungkan gaya kepemimpinan berorientasi manusia dan berorientasi tugas. Hal ini dikarenakan masingmasing gaya kepemimpinan memiliki kelemahan. Gaya kepemimpinan berorientasi tugas berfokus pada aspek teknis dengan menjelaskan prosedur-prosedur kerja namun tidak memperhatikan motivasi dan kesejahteraan bawahannya. Gaya kepemimpinan berorientasi manusia berfokus pada hubungan positif, menciptakan kerjasama tim yang baik. Namun gaya kepemimpinan ini juga memiliki kelemahan yaitu tujuan aktual menjadi lemah. Gaya kepemimpinan yang baik adalah gaya kepemimpinan yang dapat menggabungkan kedua gaya kepemimpinan ini. Sampel penelitian ini berjumlah 27 satuan kerja di Kabupaten Bandung Barat. Peneliti mengumpulkan data dengan menyebarkan kuesioner masing-masing sebanyak 4 responden ke 27 satuan kerja di Kabupaten Bandung Barat. Responden penelitian adalah pengelola keuangan berasal dari satuan kerja. Alat analisis data yang digunakan adalah regresi sederhana. Hasil penelitian menunjukkan bahwa gaya kepemimpinan berpengaruh positif secara signifikan terhadap produktivitas kerja pegawai.

Kata Kunci: gaya kepemimpinan, produktivitas kerja pegawai, pemerintah daerah 


\section{PENDAHULUAN}

Sumber daya manusia merupakan aset penting bagi organisasi baik sektor swasta maupun sektor publik, karena manusia merupakan unsur penting dalam setiap organisasi. Keberhasilan suatu organisasi dalam mencapai tujuan dan sasaran, serta kemampuan dalam menghadapi berbagai tantangan internal dan eksternal akan ditentukan oleh sumber daya manusia yang kompeten. Untuk mendapatkan sumberdaya manusia yang kompeten, maka harus dikelola secara profesional sehingga produktivitas kerja dapat tercapai secara optimal. Produktivitas kerja pegawai yang tinggi dan baik, akan diperoleh jika jajaran pimpinan organisasi memimpin dengan baik dan bijak. Karena tugas seorang pemimpin adalah mendorong bawahannya untuk memiliki kompetensi yang sesuai dengan pekerjaan. Produktivitas merupakan hal yang penting bagi pegawai suatu organisasi, supaya pekerjaan dapat terlaksa secara efisien dan efektif.

Sumber daya manusia yang kompeten dalam bekerja akan meningkatkan produktivitas organisasi yang bersangkutan. Sumber daya manusia merupakan setiap pegawai yang bekerja di suatu instansi, dapat merupakan pimpinan atau manajerial dalam suatu organisasi, memiliki peranan yang sangat penting secara internal dan juga eksternal (Sakinah AS \& Anang Suprianto, 2017) dan juga bawahan Satriadi, D. (2016). Setiap pemimpin akan mempunyai gaya masing-masing dalam memimpin anak buahnya, hal tersebut dilakukan untuk meningkatkan produktivitas kerja mereka Zebua, Martin (2017). Gaya kepemimpinan merupakan salah satu faktor penting untuk meningkatkan produktivitas kerja pegawai (Sakinah AS \& Anang Suprianto, 2017), dengan menerapkan gaya kepemimpinan berorientasi pada orang dan pada pekerjaan Nafi, M, (2001). Demikian pula di pemerintah daerah, karena kepala pemerintahan dipilih langsung oleh masyarakat, dan salah satu pemilihnya adalah pegawai pemerintah. Jika gaya kepemimpinannya hanya merupakan pencitraan saja, maka pertanggungjawaban opersional pemda dan pelayanan kepada publik tidak maksimal.

Saat ini sebagian besar penelitan meneliti tentang pengaruh gaya kepemimpinan terhadap produktivitas kerja pegawai difokuskan pada perusahaan, sedangkan penelititian yang dilakukan pada pemerintah daerah lebih banyak fokus pada satu dinas saja, dan masih jarang penelitian pada semua dinas yang ada dalam satu pemerintah daerah. Beberapa penelitian yang dilakukan di perusahaan ataupun di dinas pemda membuktikan bahwa gaya kepemimpinan memiliki pengaruh positif terhadap produktivitas kerja (Satriadi, D., 2016; Nilda dkk, 2015; Erimasyah, Teofilus 2015; Latief, Abdul, 2015; Zebua, Martin, 2017). Para peneliti ini melakukan penelitian untuk membuktikan adanya pengaruh positif gaya kepemimpinan terhadap produktivitas kerja, dan hasilnya memperlihatkan dukungan terhadap pernyataan tersebut. Penelitian yang dilakukan ini untuk menguji seberapa besar pengaruh gaya kepemimpinan terhadap produktivitas kerja pegawai.

Adapun perbedaan dengan penelitian yang sebelumnya, penelitian ini dilakukan pada sektor pemerintah dengan fokus hanya pada pengelola keuangan di semua SKPD yang ada pada pemerintah daerah tersebut. Karena sampai saat ini walaupun sudah 
hampir sepuluh tahun diterbitkan PP 71 tahun 2010 tentang SAP dan lima tahun penerapan PP 71 tahun 2010 tentang SAP, masih banyak tantangan yang dihadapi oleh pemerintah pusat dan juga pemerintah daerah dalam penerapan akuntansi berbasis akrual, yaitu: a) sistem akuntansi dan IT based system; b) komitmen pimpinan; c) tersedianya SDM yang kompeten, dan 4) resistensi terhadap perubahan. Simajuntak, Binsar 2010. Sedangkan hasil pemeriksaan BPK dalam Ihtisar Hasil Pemeriksaan Semester 1 tahun 2019, menyebutkan bahwa kualitas laporan keuangan daerah semakin meningkat dan capaian opini WTP telah melampaui target kinerja keuangan daerah yang sudah ditetapkan dalam RPJMN 2015-2019. Namun demikian masih banyak permasalahan yang terjadi pada pemerintah daerah, yaitu SPI dan Kepatuhan pada peraturan. Kelemahan dalam SPI, yaitu kelemahan struktur SPI (22\%) terjadi pada 466 pemda; kelemahan sistem pengendalian akuntansi dan pelaporan (31\%) terjadi pada 520 pemda; kelamahan sistem pengendalian pelaksanaan anggaran pendapatan dan belanja (47\%) terjadi pada 531 pemda. Selain itu SOP yang belum disusun/ tidak lengkap sebanyak 297 pemda; SOP yang belum optimal sebanyak 351 pemda dan SPI yang tidak optimal terjadi pada 122 pemda (BPK RI 2019). Hal ini memperlihatkan kondisi sumber daya manusia yang bekerja di pemerintah daerah tersebut sedang bermasalah. Selain itu BPK menyebutkan bahwa pejabat berwenang belum optimal melakukan pemahaman akuntansi dan pelaporan kepada pelaksana tugas, serta belum optimal dalam melakukan pengawasan dan pengendalian terhadap penatausahaan dan pengakuntansian pendapatan dan belanja (BPK RI, 2019).

Oleh karena itu penelitian ini untuk mengetahui gaya pimpinan (bendahara penerimaan dan bendahara pengeluaran, kepala dinas) dalam memimpin, mengarahkan bawahan (PPK-SKPD) dalam melakukan penatausahaan, pengakuntasian dan pelaporan keuangan yang sesuai dengan PP 71 tahun 2010 tentang SAP. Sehingga penatausahaan, pengakuntansian dan pelaporan keuangan dapat dilakukan dan diselesaikan sesuai waktu yang sudah ditentukan.

\section{TINJAUAN PUSTAKA}

Kepemimpinan merupakan komponen penting dalam suatu organisasi, tanpa menghilangkan arti penting komponen lain dalam suatu organisasi, karena kepemimpinan seseorang dapat mewarnai organisasi yang dipimpinnya (Indrawati, Lili, 2012). Selain itu kepemimpinan merupakan usaha dengan menggunakan suatu gaya untuk mempengaruhi dan tidak memaksa untuk memotivasi pekerja dalam mencapai tujuan atau sasaran yang sudah ditargetkan (Nafi, M, 2001, Latief, Abdul, 2015), Tugas seorang pemimpinlah untuk mendorong bawahannya agar memiliki kompetensi melalui pelatihan dan dukungan serta mengkondisikan bawahan memiliki kesempatan untuk tumbuh dan berkembang dalam mengantisipasi tantangan dan peluang untuk bekerja di bawah kondisi mandiri (Latief, Abdul, 2015). Dengan kata lain kepemimpinan merupakan kemampuan seseorang untuk memengaruhi sekelompok individu kearah pencapaian tujuan (Erimasyah, Teofilus, 2015). Bentuk atau pola kepemimpinan dapat dibedakan dari gaya kepemimpinan yang diterapkan. Gaya kepemimpinan merupakan pola tingkah laku yang dirancang untuk 
mengintegrasikan tujuan organisasi dengan tujuan individu untuk mencapai suatu tujuan tertentu (Satriadi, D., 2016; Purnama, H., 2012). Oleh karena itu gaya kepemimpinan merupakan pola tingkah laku para pemimpin dalam mengarahkan para bawahannya untuk mengikuti kehendak pemimpin tersebut dalam mencapai suatu tujuan (Latief, Abdul, 2015). Walaupun demikian gaya kepemimpinan ini tidak dapat diterapkan dalam segala kondisi.

Pada masa ini manajerial di pemerintahan sudah mulai mengubah gaya kepemimpinan mereka, yaitu dari otoriter menjadi gaya kepemimpinan berorientasi pada tugas dan berorientasi pada orang (Indrawati, Lili, 2012). Gaya berorientasi pada tugas yaitu seorang pemimpin mengarahkan dan mengawasi bawahannya selama mengerjakan tugas yang diberikannya, sedangkan yang berorientasi pada orang yaitu pemimpin selalu memotivasi bawahannya saat mengerjakan tugas dan melibatkan mereka dalam pengambilan keputusan (Indrawati, Lili, 2012; Erimasyah, Teofilus, 2015; Latief, Abdul, 2015; Nilda,dkk, 2015). Kedua gaya tersebut memperlihatkan bahwa pemimpin berusaha membuat komunikasi dua arah yang baik dengan para bawahannya.

Pada tahun 1979 International Labour Organization mendifinisikan produktivitas sebagai hubungan antara hasil nyata maupun fisik dengan masukan yang sebenarnya (Hasibuan, H. Malayu SP. 2016). Selain itu produktivitas kerja merupakan prestasi karyawan dilingkungan kerjanya (Gaol, Jummy L. 2014; Latief, Abdul, 2015) dan merupakan hasil kongkrit (produk) yang dihasilkan oleh individu atau kelompok, selama satuan waktu tertentu dalam suatu proses kerja (Yuniarsih, Tjutju, Suwatno. 2016; Nilda dkk, 2015), serta merupakan perbandingan antara output dengan input, yang mana outputnya harus mempunyai nilai tambah dan teknik pengerjaan yang lebih baik (Hasibuan, H. Malayu SP, 2016; Sakinah AS \& Anang Suprianto, 2017). Produktivitas kerja merupakan suatu sikap mental yang selalu mempunyai pandangan bahwa mutu kehidupan hari ini harus lebih baik daripada kemarin, dan hari esok harus lebih baik lagi dari hari ini (Sakinah AS \& Anang Suprianto, 2017; Erimasyah, Teofilus, 2015). Oleh karena itu produktivitas yang tinggi merupakan cerminan pegawai yang merasa puas dengan pekerjaannya dan akan memenuhi semua kewajibannya sebagai pegawai. Produktivitas kerja dapat dinilai melalui faktor pendidikan, disiplin kerja dan pengalaman kerja. Tingginya kesadaran akan pentingnya produktivitas akan mendorong pegawai tersebut untuk melakukan tindakan yang produktif.

Pihak manajerial atau pimpinan pemda memiliki tugas yang sangat berat, yaitu mereka harus selalu berusaha untuk meningkatkan kinerja dan memberikan motivasi kepada bawahannya agar selalu dapat meningkatkan produktivitas kerja sehingga tujuan yang ditetapkan dapat tercapai (Ongi, Aristo, 2015; Nilda dkk, 2015). Oleh karena itu manajerial harus lebih fleksibel dan lebih mendorong terjadinya partisipasi dan pemberdayaan bawahan dalam organisasi dengan sistem komunikasi yang mengalir secara bebas dan terkendali dari segala arah (Indrawati, Lili, 2012; Nilda dkk, 2015; Latief, Abdul, 2015). 
Upaya manajerial dalam meningkatkan kinerja bawahan tercermin dari gaya kepemimpinan yang mereka terapkan. Pada umumnya terdapat dua gaya kepemimpinan yang sering diterapkan yaitu gaya kepemimpinan berorientasi tugas dan gaya kepemimpinan berorientasi orang. Namun kedua gaya kepemimpinan ini memiliki kelebihan dan kelemahan masing-masing. Gaya kepemimpinan berorientasi tugas berfokus pada aspek teknis dengan menjalankan prosedur-prosedur kerja namun kurang mampu memotivasi karyawan. Sedangkan gaya kepemimpinan berorientasi orang menekankan pada hubungan positif antara atasan dan bawahan, namun gaya kepemimpinan ini juga memiliki kelemahan yang berkaitan dengan tujuan actual yang melemah. Oleh sebab itu, gaya kepemimpinan yang baik adalah gaya kepemimpinan yang mampu menggabungkan kedua gaya kepemimpinan tersebut. Penelitian ini menggunakan gaya kepemimpinan yang menggabungkan kedua gaya kepemimpinan tersebut. Berdasarkan kajian tersebut maka hipotesis penelitian yang disusun adalah:

H1: Gaya kepemimpinan berpengaruh terhadap produktivitas kerja pegawai.

\section{METODE PENELITIAN}

Sampel dalam penelitian ini adalah 27 unit kerja (SKPD) di Kabupaten Bandung Barat. Penelitian ini mengambil responden dengan karakteristik memiliki wewenang untuk mengatur, mengarahkan bawahan (PPK-SKPD) dalam melakukan penatausahaan, pengakuntasian dan pelaporan keuangan yang sesuai dengan PP 71 tahun 2010 tentang SAP. Sehingga diperoleh yang menjadi responden penelitian masing-masing 4 orang dari setiap SKPD yaitu kepala dinas, bendahara pengeluaran, bendahara penerimaan dan pelaksana. Kuesioner yang disebarkan ke 108 orang responden di Kabupaten Bandung Barat. Namun yang kembali 97 kuesioner dan yang dapat dianalisa hanya sebanyak 95 kuesioner saja. Metode pengumpulan data dilakukan dengan penelitian lapangan (field research), sumber data yang digunakan dan dianalisis adalah jenis data primer (primary data). Adapun variabel yang diteliti adalah gaya kepemimpinan (leadership style) dan produktivitas kerja pegawai.

Gaya kepemimpinan merupakan variabel independen dan produktivitas kerja pegawai merupakan variabel dependen, yang diukur menggunakan instrumen pengukuran dalam bentuk kuesioner yang bersifat tertutup dengan skala likert. Setiap jawaban diberi skor dengan tingkat pengukuran ordinal. Indikator gaya kepemimpinan dan produktivitas kerja pegawai menggunakan indikator yang pernah digunakan Indrawati, Lili, (2012), sedangkan untuk indikotor produktivitas kerja pegawai menggunakan indikator dari Indrawati, L., \& Sembiring, E. ernita. (2019)

Pengujian awal yang akan dilakukan adalah uji validitas dan uji reliabilitas untuk melihat kesahihan dan keandalan alat ukur yang digunakan. Alat uji validitas yang digunakan adalah dengan melihat signifikansi korelasi antara nilai item pertanyaan dengan nilai total pertanyaaan. Dasar pengambilan keputusan yaitu jika tingkat signifikansi berada di bawah 0,05 maka korelasi tersebut bersifat signifikan yang berarti alat ukur yang digunakan valid sedangkan alat uji reliabilitas yang digunakan adalah cronbach alpha. Dasar pengambilan keputusan yaitu jika nilai cronbach alpha lebih besar dari 0,6 maka alat ukur yang digunakan bersifat reliabel. Selanjutnya dilakukan 
uji normalitas data. Alat yang digunakan untuk menguji normalitas data adalah metoda Kolmogrov-Smirnov (K-S) . Dasar pengambilan keputusan yaitu data dikatakan berdistribusi normal jika nilai probabilitas lebih besar dari 0,05 namun jika nilai probabilitas lebih kecil dari 0,05 maka data berdistribusi tidak normal. Setelah dilakukan uji normalitas maka dilakukan uji hipotesis dengan uji regresi sederhana.

\section{HASIL DAN PEMBAHASAN}

\subsection{Uji validitas dan reliabilitas}

Berdasarkan hasil uji korelasi item pertanyaan terhadap nilai total pertanyaan diproleh nilai tingkat signifikansi berada dibawah 0,05 dan ini menunjukkan alat ukur yang digunakan bersifat valid. Hasil dari pengujian reliabilitas menunjukkan nilai Cronbach Alpha untuk masing-masing variabel yang lebih besar dari 0,06 yaitu 0,726 untuk gaya kepemimpinan dan 0,705 untuk produktivitas kerja pegawai sehingga dapat ditarik kesimpulan alat ukur yang digunakan valid.

\section{$4.2 \mathrm{Uji}$ normalitas}

Uji normalitas menggunakan uji Kolmogrov-Smirnov (K-S) dengan jumlah data sebanyak 95 namun hasil menunjukkan tingkat signifikansi sebesar 0,07 yang berarti data tidak berdistribusi normal. Lalu dilakukan transform data dengan melakukan $\ln$ dan $\log 10$ untuk menormalkan data namun data tetap tidak berdistribusi normal sehingga dilakukan pembuangan data outlier. Data yang semula berjumlah 95 berubah menjadi 69. Hasil uji Kolmogrov-Smirnov (K-S) setelah dilakukan pembuangan data yaitu 0.191 sehingga dapat dikatakan data berdistribusi normal.

\subsection{Statistik Deskriptif}

Berikut adalah tabel statistik deskriptif penelitian

Tabel 4.1 Statistik deskriptif

\begin{tabular}{|l|c|c|c|c|c|}
\hline \multicolumn{1}{|c|}{ Variabel } & n & Min & Maks & Mean & Deviasi standar \\
\hline Gaya kepemimpinan & 69 & 3,33 & 5 & 4,1622 & 0,351 \\
\hline $\begin{array}{l}\text { Produktivitas kerja } \\
\text { pegawai }\end{array}$ & 69 & 3,43 & 5 & 4,0659 & 0,354 \\
\hline
\end{tabular}

(Sumber : data diolah)

Berdasarkan tabel di atas dapat dilihat nilai gaya kepemimpinan dan produtivitas kerja pegawai adalah tinggi, ini dapat dilihat nilai terendah dari kedua variabel berada di atas nilai tengah 3 dengan rata rata 4,1622 untuk gaya kepemimpinan dan 4,0659 untuk produktivitas kerja pegawai hampir mendekati nilai maksimum yaitu 5

\subsection{Hasil uji hipotesis}

Berdasarkan hasil uji regresi sederhana diperoleh persamaan regresi sebagai berikut:

$$
\mathrm{Y}=1,976+0,502 \mathrm{X}+\mathrm{e}
$$

Keterangan:

$\mathrm{Y}=$ produktivitas kerja pegawai

$\mathrm{X}=$ gaya kepemimpinan

$\mathrm{e}=$ eror 
Berdasarkan persamaan di atas dapat diketahui produktivitas kerja pegawai akan mengalami peningkatan sebesar 0,502 setiap adanya peningkatan gaya kepemimpinan. Adapun nilai adjusted koefisien determinasi adalah sebesar 0.238 , yang memperlihatkan bahwa variabel gaya kepemimpinan dapat menjelaskan variasi perubahan produktivitas kerja pegawai sebesar $23,8 \%$, sedangkan sisanya sebesar $76,2 \%$ dijelaskan oleh variabel lain yang tidak termasuk pada penelitian ini. Dilihat dari tingkat signifikansi menunjukkan nilai 0,000 lebih kecil dari 0,05 yang menunjukkan gaya kepemimpinan berpengaruh signifikan terhada produktivitas kerja pegawai sehingga hipotesis yang diajukan didukung. Hasil penelitian ini sesuai dengan hasil penelitian sesuai dengan penelitian Dimas Satriadi (2017), Sakinah AS \& Anang Suprianto (2017), Martin Zebua (2017) dan juga Abdul Latief (2015).

\subsection{Diskusi}

Hasil penelitian menunjukkan dukungan terhadap hipotesis yang menyatakan gaya kepemimpinan memiliki pengaruh secara signifikan terhadap produktivitas kerja pegawai. Namun yang harus diperhatikan oleh pimpinan adalah tidak ada satu jenis gaya kepemimpinan yang terbaik. Gaya kepemimpinan atasan yang efektif tergantung dari karakteristik organisasi dan karakteristik bawahan. Atasan harus mampu mengenali dan menganalisa karakteristik bawahannya sehingga dapat menentukan gaya kepemimpinan yang efektif. Hal ini sama seperti pernyataan Zebua, Martin (2017) yaitu setiap pemimpin akan mempunyai gaya masing-masing dalam memimpin anak buahnya, hal tersebut dilakukan untuk meningkatkan produktivitas kerja mereka. Gaya kepemimpinan yang efektif mampu mempengaruhi sikap dan perilaku bawahan kearah yang lebih baik serta meningkatkan produktivitas. Atasan yang disegani dan dipercaya oleh bawahan dapat meningkatkan motivasi intrinsic bawahan. Bawahan akan berusaha meningkatkan produktivitas mereka agar tidak mengecewakan atasan mereka.

\section{PENUTUP}

Penelitian ini dilakukan berdasarkan pada hasil dari pemeriksaan BPK, yang memperlihatkan bahwa masih tetap ada pegawai pemda yang terlibat dalam pengelolaan keuangan tapi masih belum optimal dalam menatausahakan dan mengakuntansikan realisasi anggaran di SKPD, walaupun PP 71 tahun 2020 tentang SAP diterapkan hampir lima tahun. Hasil penelitian menunjukkan bahwa gaya kepemimpinan berpengaruh signifikan terhadap produktivitas kerja pegawai dalam penatausahaan dan pengakuntansian realisasi pendapatan dan belanja. Hasil penelitian ini sesuai dengan penelitian Dimas Satriadi (2017), Sakinah AS \& Anang Suprianto (2017), Martin Zebua (2017) dan juga Abdul Latief (2015). Nilai adjusted koefisien determinasi pada penelitian adalah sebesar 0.238 , yang memperlihatkan bahwa variabel gaya kepemimpinan dapat menjelaskan variasi perubahan produktivitas kerja pegawai sebesar $23,8 \%$. Hal ini dikarenakan produktivitas kerja bawahan di SKPD dipengaruhi oleh banyak faktor yang lain seperti skema kompensasi, peraturan 
yang berlaku, budaya organisasi dan factor lainnya sehingga meskipun nilai adjusted koefisien determinasi hanya $23,8 \%$ namun sudah mampu mempengaruhi produktivitas kerja pegawai. Implikasi akademis yang diperoleh dari hasil penelitian ini yaitu mendapatkan bukti empiris bahwa gaya kepemimpinan berpengaruh secara signifikan terhadap produktivitas kerja pegawai. Sedangkan implikasi manajerial yang diperoleh yaitu hasil penelitian ini menjadi salah satu masukan bagi pihak manajerial/structural mengenai arti penting gaya kepemimpinan dalam mempengaruhi produktivitas kerja pegawai. Gaya kepemimpinan yang tepat akan dapat menimbulkan komitmen bagi pegawai untuk bekerja dengan lebih baik

\section{DAFTAR PUSTAKA}

Aulia, Figur (2017). Pengaruh Kepemimpinan Terhadap Produktivitas Kerja Pegawai di Kantor Dinas Kesejahteraan Sosial Kota Samarinda, eJournal Ilmu Pemerintahan , 2017, 5 (2): 593-604

AS, S., \& Suprianto, A. (2017). Pengaruh Kepemimpinan Terhadap Produktivitas Kerja Karyawan Bagian Multifuel Boiler pada PT.Lontar Papyrus Pulp and Paper Industry. J-MAS (Jurnal Manajemen Dan Sains). https://doi.org/10.33087/jmas.v2i1.15

BKP RI, 2019. Ikhtisar Hasil Pemeriksaan Semester I 2019

Erimasyah, Teofilus (2015). Pengaruh Gaya Kepemimpinan terhadap Produktivitas Warehouse PT Theis site Melak, Kutai Barat, FE Universitas 17 Agustus 1945 Samarinda

Gaol, Jummy L. (2014). Human Capital Manajemen Sumber Daya Manusia, Penerbit PT Gramedia Widiasarana Indonesia, Jakarta.

Hasibuan, H. Malayu SP. (2016). Manajemen Sumber Daya Manusia. PT Bumi Aksara, Jakarta.

Indrawati, Lili, (2012). Peran Budaya Organisasi, Gaya Kepemimpinan dan Intellectual Capital Terhadap Implementasi New Public Management Dalam Peningkatan Kinerja Manajerial Sektor Publik. Program Pasca Sarjana Universitas Jenderal Soedirman, Purwokerto

Indrawati, L., \& Sembiring, E. ernita. (2019). Pengaruh Intellectual Capital terhadap Produktivitas Kerja Pegawai di Pemerintah Daerah. Ekspansi: Jurnal Ekonomi, Keuangan, Perbankan Dan Akuntansi. https://doi.org/10.35313/ekspansi.v11i2.1559

Latief, Abdul (2015). Pengaruh Gaya Kepemimpinan dan Motivasi Terhadap Produktivitas Kerja Karyawan pada Afdeling Prapen I Kebun Unit 1 PT Mopoli Raya Kabupaten Langkat. Jurnal Manajemen dan Keuangan, Vol 4, No 1, Mei 2015.

Mahmudi, (2010). Manajemen Kinerja Sektor Publik, Edisi Kedua, Unit Penerbit dan Percetakan STIE YKPN, Yogyakarta.

Mensah, Philip \& Addaquay AS and Davis, MS (2018). Effects of Leadership Styles on Productivity of Secretary in The Public Sector in Ghana. International Journal of Business and Management Review Vol.6, No.10, pp.14-32, November 2018 
Nafi, M, (2001), Pengaruh Gaya Kepemimpinan, Ketidakpastian Lingkungan terhadap Partisipasi Anggaran, Tesis Universitas Gajah Mada Yogyakarta.305-360

Nilda \& Ruliana, Titin \& Lau, Efreda A. (2015). Pengaruh Kepemiminan terhadap Produktivitas Kerja Pegawai pada Kantor Dinas Kesehatan Kabupaten Kutai Barat, FE Universitas 17 Agustus 1945 Samarinda

Ongi, Aristo, 2015. Pengaruh Budaya Organisasi dan Motivasi Kerja Terhadap Produktivitas Karyawan pada PT Nusa Halmahera Minerals di Kab. Halmahera Utara, e-journal.unsrat.ac.id>index.php>JAP>article>view.

Purnama, H. (2012). Pengaruh Gaya Kepemimpinan terhadap Produktivitas Kerja Karyawan Bagian Bengkel pada CV Mitra Denso di Bandar Lampung . Jurnal Organisasi dan Manajemen .(34-45)

Satriadi, D. (2016). Pengaruh Kepemimpinan Kepala Sekolah Terhadap Kinerja Guru. Jurnal Benefita, 1(3), 123. https://doi.org/10.22216/jbe.v1i3.874

Sekaran, Uma dan Roger Bougie, (2017), Metode Penelitian untuk Bisnis: Pendekatan Pengembangan-Keahlian,Edisi 6, Buku 1 \& 2, Salemba Empat, Jakarta Selatan 12610.

Simanjuntak, Binsar H, 2010. Penerapan Akuntansi Berbasis Akrual di Sektor Pemerintahan di Indonesia. Disampaikan padaKongres XI Ikatan Akuntan Indonesia. Jakarta

Tewari, S., Gujarathi, R., \& Maduletty, K. (2019). Leadership Styles and Productivity. Asian Social Science. https://doi.org/10.5539/ass.v15n4p115

Yuniarsih, Tjutju, Suwatno. (2016). Manajemen Sumber Daya Manusia, Bandung, Alfabeta.

Zebua, Martin (2017). Pengaruh Gaya Kepemimpinan terhadap Produktivitas Kerja Karyawan pada PT Coca Cola Cabang Malang, Jurnal Media Mahardika, Vol 15, No 3, Mei 2017 